\title{
RESEARCH PAPER \\ Effect of the type of substrate on the chemical composition and productivity of a protein concentrate of yeast origin
}

\author{
Alejandro Velásquez ${ }^{1,2}$, Rodrigo Arias ${ }^{1,2}$, and Marcelo Toneatti ${ }^{1}$ \\ ${ }^{1}$ Escuela de Agronomía, Facultad de Recursos Naturales. ${ }^{2}$ Núcleo de Investigación en Producción \\ Alimentaria. Universidad Católica de Temuco. Manuel Montt 56, Temuco, Chile.
}

\begin{abstract}
A. Velásquez, R. Arias, and M. Toneatti 2012. Effect of the type of substrate on the chemical composition and productivity of a protein concentrate of yeast origin. Cien. Inv. Agr. 39(3): 425-434. Extracts of Saccharomyces cerevisiae (Sc) yeast were generated using a biotechnological solid-state fermentation method. The organic material used for fermentation consisted of a variety of fibrous substrates of agricultural origin, and their effect on the chemical composition and productivity of cellular biomass generated was evaluated. The substrates studied included the following: wheat straw, WS; barley straw, BS; chili stubble, CS; oat hull, $\mathrm{OH}$ and starch powder, SP (control). For incubation with Sc, $2 \mathrm{~g}$ of (dry) vegetable substrate were added to $12 \mathrm{~mL}$ of cultivation medium. The fermentation time was seven days under aerobic conditions $\left(\mathrm{pH} 5,26^{\circ} \mathrm{C}\right)$. After extraction of the yeast biomass, its chemical composition and productivity were analyzed. The results showed an effect $(\mathrm{P} \leq 0.01)$ of the type of vegetable substrate fermented on the crude protein (CP) and true protein (TP) contents of the yeast biomass. The highest concentration of $\mathrm{CP}$ was obtained by fermentation of the control TSP (treatment with the starch powder substrate ) $\left(506.3 \mathrm{~g} \mathrm{~kg}^{-1} \mathrm{DM}\right)$, followed by the treatment TOH (474.5 $\left.\mathrm{g} \mathrm{kg}^{-1} \mathrm{DM}\right)$. The productivity of the yeast biomass was affected by the type of substrate fermented $(\mathrm{P} \leq 0.001)$. The highest value was obtained with TSP $\left(327.10 \mathrm{mg} \mathrm{g}^{-1}\right)$, followed by TOH (treatment with the oat hull substrate) $\left(207.08 \mathrm{mg} \mathrm{g}^{-1}\right)$. The lowest efficiency was measured in TCS (156.30 mg g-1). On the basis of these results, it may be inferred that an extract of high $\mathrm{CP}$ can be obtained from yeast $(\mathrm{Sc})$ by the fermentation of fibrous substrates.
\end{abstract}

Key words: protein concentrate, Saccharomyces cerevisiae, vegetable substrate.

\section{Introduction}

Protein concentrates of yeast origin constitute an innovative alternative for providing amino acids to animals, preferably non-ruminants (Robinson

Received March 20, 2012. Accepted July 2012.

Corresponding author: avelasquez@uct.cl and Nigam, 2003; Ghaly et al., 2005). The production of yeast protein through the fermentation of fibrous vegetable substrates in bioreactors is a viable biotechnological option for generating protein concentrates of high nutritional value (Rostami et al., 2009). Yeast normally present a varied and potent pool of hydrolytic enzymes, enabling them to depolymerize the structural 
constituents of the cell walls of plants (cellulose, lignin, hemicellulose and pectin) and, thus, to proceed with enzymatic digestion inside the cells. However, the fibrolytic potential of Saccharomyces cerevisiae (Sc) is unknown, and it has been assumed to be unable to exploit the cell walls of the substrates to be fermented. Various species of fungi have been used to generate protein, particularly those belonging to the genera Saccharomyces, Trichoderma and Aspergillus (Domsch et al., 1980; Antier et al., 1993; VillasBôas, 2002; Kacmar et al., 2004; Pereira et al., 2010). Saccharomyces cerevisiae (Sc) is the most representative species of the Saccharomyces genus and is one of the microorganisms most frequently used for generating additives for farm animal feed (prebiotic and probiotic). One of its principal advantages is that it does not generate mycotoxins; it is therefore considered to be one of the most innocuous for human consumption and for feeding to farm animals (Lehloenya et al., 2008; Bruno et al., 2009). It is also used as a feed supplement due to its high contribution of crude proteins (CP) (close to 50\%) and B-complex vitamins, such as niacin, folic acid, riboflavin and biotin (Nielsen and Jewett, 2008; Jung et al., 2010). This fungus has a complete enzyme pool that functions to degrade organic matter and is generally used to produce protein concentrates under in vitro conditions and on an industrial scale (Brock, 1998; Pakula et al., 2005). These enzymatic properties raise great hopes for the use of yeast in animal nutrition given their high biological potential to ferment organic matter of diverse origins (El-Nawwi and El-Kader, 1996; Rollini and Manzoni, 2006; Bai et al., 2008). One example is the work of Kamel (1979), who studied strains of $\mathrm{Sc}$ in order to produce protein, using date juice as the substrate. The cell mass generated after a 12 -h fermentation was $4.86 \mathrm{~g} \mathrm{~L}^{-1}$ of incubation medium, resulting in a productivity of approximately $2.6 \mathrm{~g} \mathrm{CP} \mathrm{L}^{-1}$. Using this same yeast but under a continuous cultivation system based on glucosamine as the fermentation substrate, Ferrer et al. (1996) achieved production of $0.447 \mathrm{~kg}$ cells $\mathrm{DM} \mathrm{kg} \mathrm{kg}^{-1}$ of fermented glucosamine, with a growth rate equal to $0.423 \mathrm{~kg}$ cells $\mathrm{m}^{-3} \mathrm{~h}^{-1}$. In another study, the authors Nwabueze and Oguntimein (1987) evaluated this yeast as a protein producer using waste from the industrial processing of sweet oranges (Citrus sinensis) as the fermentation substrate. After a 12 -h incubation $\left(\mathrm{pH} 5.5,36^{\circ} \mathrm{C}\right)$, cellular biomass was produced in a proportion of $4 \%(\mathrm{w} / \mathrm{w})$ of the citrus sp. waste containing $57 \%$ CP. Silva et al. (2011) evaluated the cellular biomass productivity of the yeast $\mathrm{Sc}$ in fermenting vinasse (residue of cachaça and bio-ethanol production). The microorganism was inoculated into a culture medium containing the following: yeast extract $(3 \%)$, vinasse $(10 \% \mathrm{v} / \mathrm{v})$, glucose $(2 \%)$, peptone $(3 \%)$ and potassium phosphate $(0.2 \%)$. Incubation was carried out at $28^{\circ} \mathrm{C}$ and $\mathrm{pH} 3$ for $192 \mathrm{~h}$. The production of cellular biomass was $8.7 \mathrm{~g} \mathrm{~L}^{-1}$ of incubation medium with a content of $9.8 \%(\mathrm{DM})$ nitrogen.

With regard to the fermentation substrates, in principle any organic matter of vegetable or animal origin can serve this purpose. The biological, chemical and physical interactions between the yeast and fermented substrate will determine the levels and efficiency of the production of biomass and cellular proteins. It is therefore of great interest to understand the effect of different fermented fibrous substrates on the nutritional quality and productivity of the cellular biomass from Sc. To this end it will also be very valuable to learn about new vegetable substrates, especially those which present low nutritional quality, low cost and high availability (Anupama and Ravindra, 2000). In the scientific literature, substrates of various origins are reported for these purposes, in particular vegetable matter with a high content of lignin and cellulose (cereal straw), agro-industrial waste (fruits, vegetables and molasses), waste paper, or by-products of the dairy industry, e.g., whey from cheese factories (Kamel, 1979; Nwabueze and Oguntimein, 1987; Ghaly et al., 2005). It has been suggested that this organic matter would provide energy, carbonate skeletons, and some nitrogenous fractions to 
microorganisms to enable them to synthesize their proteins (Zheng et al., 2005; Najafpour, 2007; Golfinopoulos et al., 2011).

In Chile, the behavior of $\mathrm{Sc}$ in protein production using certain types of fibrous vegetable matter as fermentable substrates (waste from crops and local agro-industry) is unknown. These are normally burnt, remain as stubble to be ploughed into the soil, left as fallow or used for direct animal consumption. In this context, and in order to make use of these potential vegetable substrates, the choice of the substrates studied in this work was based on the following criteria: 1) Fiber content-substrates with a high cell wall (NDF: neutral detergent fiber) and lignocelluloses (ADF: acid detergent fiber) content were evaluated and compared with other substrates that present a low fiber content, greater calorie density and higher content of fast-fermenting carbohydrates. 2) Availability and low cost-large quantities of wheat and barley straw and chili stubble (Merkén) are generated in the Araucanía Region due to the widespread cultivation of these crops. Large quantities of oat hull are also produced in the Region as a waste product from industrial oats processing.

Consequently, the object of this research was to evaluate the effect of fermentation of different vegetable substrates on the chemical composition and productivity of the protein concentrate generated by Sc.

\section{Materials and methods}

The yeast protein was produced using the solid-state fermentation biotechnological method (Jay, 2000; Ghaly et al., 2005). This technique involved the aerobic fermentation of yeast inocula on selected vegetable substrates in bioreactors. The effect of the type of fermented vegetable substrate on the chemical composition (nutritional quality) and productivity of the yeast biomass were evaluated in a single experiment.
Effect of the type of substrate fermented on the chemical composition and productivity of the yeast protein concentrate

The Sc strains (ATCC-13507) were provided by the microbiology laboratory of the School of Veterinary Medicine of Universidad Católica de Temuco. The inocula were cultivated in Petri dishes using potato dextrose agar (PDA) as the propagation substrate. The cultures were incubated at $28^{\circ} \mathrm{C}$ for 4 days. After propagation, spores were collected from the surface of the dishes and deposited in $10 \mathrm{~mL}$ of distilled water. The doses were then prepared for incubation in the vegetable substrates. To do this, the number of spores $\mathrm{mL}^{-1}$ was determined using a haemocytometer (Neubauer). A solution was then prepared in distilled water at $25^{\circ} \mathrm{C}$, establishing a final concentration of $6.7 \times 10^{6}$ spores $\mathrm{mL}^{-1}$.

The following substrates were evaluated: 1) wheat straw: WS (Triticum aestivum) 2) barley straw: BS (Hordeum vulgare) 3) chili stubble: CS (Capsicum annuum) 4) oat hull: $\mathrm{OH}$ (Avena sativa) and 5) starch powder: SP (Riedel-deHaën 33615-7111A). The latter substrate was the control for the experiment. Each treatment was corrected with the respective blanks, consisting of incubations of the substrates with no inoculum. Additionally, the basal input of inoculum by incubation of yeast (Sc spores) in the culture medium was corrected with an inert material without organic substrate. Samples of each substrate were formed by five sub-samples $(0.5 \mathrm{~kg})$, which were mixed for evaluation. The WS, BS and CS substrates were obtained from stubble of crops grown in the Araucanía Region. $\mathrm{OH}$ is the by-product of the industrial processing of oats for human and animal consumption and is also from the Araucanía Region. During the collection of the substrates in the field (WS, BS and $\mathrm{CS}$ ), vegetable material free of visible structural damage and with the least impurity contamination was selected. Care was also taken to ensure the absence of possible phytopathogenic agents (visual inspection), and the lack of these agents was checked again under a microscope in the laboratory. The samples were then washed with 
distilled water for $15 \mathrm{~min}$, autoclaved at $121^{\circ} \mathrm{C}$ for $20 \mathrm{~min}$, and finally dried in a stove at $60{ }^{\circ} \mathrm{C}$ for $48 \mathrm{~h}$. They were chopped to a size range of $0.1-0.3 \mathrm{~cm}$. For incubation (bioreactor), $250 \mathrm{~mL}$ Erlenmeyer flasks were used, fitted with a glass and rubber device to ensure aerobic conditions and avoid microbiological contamination. The flasks were sterilized with alcohol (98\%) and UV radiation (Laminar Flow Cabinet: STREAMLINE SHC4A1) for $30 \mathrm{~min}$. Then, $2 \mathrm{~g}$ of vegetable substrate (dry) was added in $12 \mathrm{~mL}$ of culture medium, which was composed of $8 \mathrm{~mL}$ of buffer Tris 50 $\mathrm{Mm}$ ( $\mathrm{pH} 5), 2 \mathrm{~mL}$ of antibiotic streptomycin (0.5 g $500 \mathrm{~mL}^{-1}$ distilled water) to prevent bacterial contamination, $1 \mathrm{~mL}$ of a solution of urea at $5 \%$ (w/v) and $1 \mathrm{~mL}$ peptone at 2\% (Sathesh-Prabu and Murugesan, 2011; Ruiz et al., 2012). The inoculation dose was $2 \mathrm{~mL}^{\text {flask }} \mathrm{k}^{-1}$ of a solution consisting of $6.7 \times 10^{6}$ spores $\mathrm{mL}^{-1}$. The incubation time was $7 \mathrm{~d}$ at a constant temperature of $26^{\circ} \mathrm{C}$.

\section{Extraction of yeast biomass}

On completion of the incubation period, 150 $\mathrm{mL}$ of distilled water $\left(2{ }^{\circ} \mathrm{C}\right)$ was added to each Erlenmeyer flask to stop microbial growth and facilitate the separation of the yeast biomass from the vegetable matter. Next, the total contents of the flask were homogenized using a blender (Waring 8010BU-CAC33) for $3 \mathrm{~min}$, and then filtered, first through cheesecloth and then through a steel mesh with pore size $100 \mu \mathrm{m}$. The filtrate was centrifuged at $6,500 \mathrm{x}$ g for $10 \mathrm{~min}$ at $4{ }^{\circ} \mathrm{C}$. The pellet obtained corresponded to the yeast biomass. It was frozen at $-32{ }^{\circ} \mathrm{C}$ until the bromatological analysis and the measurement of the mass produced were carried out.

\section{Determination of the chemical composition of vegetable substrates and yeast biomass}

The vegetable substrates (WS, BS, CS, $\mathrm{OH}$ and SP) and the yeast biomass pellets (TWS: treatment with the wheat straw substrate, TBS: treatment with the barley straw substrate, TCS: treatment with the chili stubble substrate, TOH: treatment with the oat hull substrate and TSP: treatment with the starch powder substrate) were subjected to chemical analysis (Table 1). The $\mathrm{N}$ (official method, 984.13), DM (official method, 934.01) and ash (official method, 942.05) contents were determined by the method developed by AOAC (1990). True protein (TP) was determined from the insoluble $\mathrm{N}$ plus the fraction of soluble $\mathrm{N}$ in the buffer, which is insoluble in TCA (Pichard and Van Soest, 1977). Plant cell wall (NDF) and lignocelluloses (ADF) were measured using the methods described by Van Soest et al. (1991). The latter was determined without the use of sodium sulfite and alpha amylase and expressed exclusive of residual ash. To determine the NDIN (insoluble $\mathrm{N}$ in neutral detergent fiber) and ADIN (insoluble $\mathrm{N}$

Table 1. Chemical composition of vegetable substrates.

\begin{tabular}{|c|c|c|c|c|c|c|c|c|c|}
\hline \multirow[b]{2}{*}{ Substrate $^{1}$} & \multirow{2}{*}{$\begin{array}{l}\mathrm{DM}^{2} \\
\mathrm{~g} \mathrm{~kg}^{2}\end{array}$} & Ash & $\mathrm{CP}$ & $\mathrm{NDF}^{3}$ & $\mathrm{ADF}$ & $\mathrm{TP}^{4}$ & $\mathrm{SN}$ & $\mathrm{NDIN}^{5}$ & ADIN \\
\hline & & \multicolumn{4}{|c|}{$\mathrm{g} \mathrm{kg}^{-1} \mathrm{DM}$} & \multicolumn{4}{|c|}{$\mathrm{g} \mathrm{kg}^{-1} \mathrm{CP}$} \\
\hline WS & $972^{6}$ & 82 & 41 & 869 & 556 & 898 & 228 & 297 & 166 \\
\hline BS & 970 & 98 & 45 & 850 & 548 & 905 & 232 & 284 & 164 \\
\hline $\mathrm{CS}$ & 968 & 71 & 48 & 875 & 662 & 887 & 183 & 305 & 179 \\
\hline $\mathrm{OH}$ & 978 & 97 & 46 & 760 & 420 & 856 & 224 & 258 & 98 \\
\hline SP & 984 & 2 & 0 & 0 & 0 & 0 & 0 & 0 & 0 \\
\hline
\end{tabular}

${ }^{1}$ WS: wheat straw, BS: barley straw, CS: chili stubble, OH: oat hull, SP: starch powder.

${ }^{2} \mathrm{DM}$ : dry matter, CP: crude protein.

${ }^{3} \mathrm{NDF}$ : neutral detergent fiber, ADF: acid detergent fiber.

${ }^{4} \mathrm{TP}$ : true protein, $\mathrm{SN}$ : N soluble fraction.

${ }^{5} \mathrm{NDIN}$ : insoluble $\mathrm{N}$ in neutral detergent, ADIN: insoluble $\mathrm{N}$ in acid detergent.

${ }^{6} \mathrm{Chemical}$ assay of three samples. 
in acid detergent fiber), Kjeldahl $\mathrm{N}$ was measured in fiber residues.

Measurement of the productivity of yeast biomass, CP and TP

The productivity was measured for the following: 1) yeast mass of protein concentrate/mass of substrate fermented, YMPC/MSF 2) mass of crude protein/mass of substrate fermented, $\mathrm{MCP} /$ MSF and 3) mass of true protein/mass of substrate fermented, MTP/MSF. The weight of the yeast biomass pellet and the fermented substrate were measured on an analytical scale after drying, following the official method, 934.01 (AOAC, 1990).

\section{Statistical analysis}

A completely random experimental design was used in the tests with a one-way analysis of variance. The only factor studied was the type of substrate fermented by the yeast (WS, BS, $\mathrm{CS}, \mathrm{OH}$ and SP); this latter was the control. The experiment was repeated three times, each time in triplicate, which allowed for nine observations per treatment. An experimental unit (EU) was an Erlenmeyer flask containing the specific yeast incubation with the substrate. The statistical model was $\mathrm{Y}_{\mathrm{ij}}=\mu+\alpha_{\mathrm{i}}+\varepsilon_{\mathrm{ij}}$, where $\mathrm{Y}_{\mathrm{ij}}=$ observed value (Chemical composition, YMPC/MSF, MCP/MSF, MTP/MSF) in TWS (treatment with the wheat straw substrate), TBS (treatment with the barley straw substrate), TCS (treatment with the chili stubble substrate), TOH (treatment with the oat hull substrate) and TSP (treatment with the starch powder substrate), $\mu=$ general mean, $\alpha_{i}=$ effect of the $i^{\text {th }}$ treatment (type of substrate), $\varepsilon_{\mathrm{ij}}=$ experimental error. Significant differences were accepted if $\mathrm{P} \leq 0.05$. Treatment means were compared according to Tukey's procedure with a level of significance of $5 \%$. The statistical studies were performed using the software SYSTAT 11 (2003, Software Inc. (SSI). California, USA) and $\mathrm{JMP}^{\circledR}$ (version 5.0.1.2, SAS Inc., Cary, NC, 2003).

\section{Results}

Effect of the type of substrate fermented on the chemical composition of the yeast protein concentrate

An effect $(\mathrm{P} \leq 0.01)$ of the type of vegetable substrate fermented on the $\mathrm{CP}$ and TP content in the yeast protein concentrate was observed (Table 2). The highest concentration of $\mathrm{CP}$ was obtained by fermentation

Table 2. Effect of type substrate fermented on the chemical composition of the protein concentrate originated by Saccharomyces cerevisiae.

\begin{tabular}{lccccccc}
\hline Chemical & \multicolumn{7}{c}{ Microbial protein concentrate $\left(\mathrm{g} \mathrm{kg}^{-1}\right)$} \\
\hline composition & TWS & TBS & TCS & TOH & TSP & SEM & $P$ \\
$\mathrm{CP}^{2}\left(\mathrm{~g} \mathrm{~kg}^{-1} \mathrm{DM}\right)$ & $432.9 \mathrm{c}$ & $440.6 \mathrm{c}$ & $389.0 \mathrm{~d}$ & $474.5 \mathrm{~b}$ & $506.3 \mathrm{a}$ & 14.3 & $\leq 0.01$ \\
$\mathrm{TP}\left(\mathrm{g} \mathrm{kg}^{-1} \mathrm{CP}\right)$ & $759.6 \mathrm{~b}$ & $758.8 \mathrm{~b}$ & $668.4 \mathrm{c}$ & $756.5 \mathrm{~b}$ & $786.1 \mathrm{a}$ & 18.2 & $\leq 0.01$ \\
$\mathrm{SN}\left(\mathrm{g} \mathrm{kg}^{-1} \mathrm{CP}\right)$ & $430.9 \mathrm{~b}$ & $428.5 \mathrm{~b}$ & $435.3 \mathrm{~b}$ & $432.5 \mathrm{~b}$ & $469.7 \mathrm{a}$ & 12.7 & $\leq 0.05$ \\
$\mathrm{NDF}^{3}\left(\mathrm{~g} \mathrm{~kg}^{-1} \mathrm{DM}\right)$ & 219.8 & 223.2 & 228.1 & 228.8 & 225.3 & 11.4 & 0.28 \\
$\mathrm{ADF}\left(\mathrm{g} \mathrm{kg}^{-1} \mathrm{DM}\right)$ & 59.2 & 61.0 & 58.4 & 56.1 & 57.7 & 5.2 & 0.16 \\
$\mathrm{NDIN}\left(\mathrm{g} \mathrm{kg}^{-1} \mathrm{CP}\right)$ & 87.7 & 89.2 & 91.1 & 88.4 & 90.0 & 6.5 & 0.13 \\
$\mathrm{ADIN}\left(\mathrm{g} \mathrm{kg}^{-1} \mathrm{CP}\right)$ & 35.4 & 36.1 & 33.9 & 36.5 & 36.4 & 4.7 & 0.21 \\
\hline
\end{tabular}

Different letters within rows indicate differences $(\mathrm{P} \leq 0.05)$.

${ }^{1}$ TWS: treatment with the wheat straw substrate, TBS: treatment with the barley straw substrate, TCS: treatment with the chili stubble substrate, TOH: treatment with the oat hull substrate, TSP: treatment with the starch powder substrate.

${ }^{2} \mathrm{CP}$ : crude protein, DM: dry matter, TP: true protein, SN: N soluble fraction.

${ }^{3} \mathrm{NDF}$ : neutral detergent fiber, ADF: acid detergent fiber.

${ }^{4} \mathrm{NDIN}$ : insoluble $\mathrm{N}$ in neutral detergent, ADIN: insoluble $\mathrm{N}$ in acid detergent. 
of the control TSP (506.3 g kg-1 DM), followed by TOH (474.5 $\left.\mathrm{g} \mathrm{kg}^{-1} \mathrm{DM}\right)$. TWS and TBS did not differ $(\mathrm{P}>0.05)$ but were significantly lower $(\mathrm{P} \leq 0.05)$ than the value observed for TOH and higher than TCS (389.0 $\left.\mathrm{g} \mathrm{kg}^{-1} \mathrm{DM}\right)$. TSP presented the highest value for TP $\left(786.1 \mathrm{~g} \mathrm{~kg}^{-1} \mathrm{CP}\right)$. TOH, TWS and TBS did not differ $(\mathrm{P}>0.05)$ with an average TP content of $758.3 \mathrm{~g} \mathrm{~kg}^{-1} \mathrm{CP}$. TCS presented the lowest TP content (668.4 $\left.\mathrm{g} \mathrm{kg}^{-1} \mathrm{CP}\right)$. At the same time, there was an effect of the substrate fermented by $\mathrm{Sc}$ on the $\mathrm{SN}$ content $(\mathrm{P} \leq 0.05)$. The highest concentration was observed with TSP (469.7 $\left.\mathrm{g} \mathrm{kg}^{-1} \mathrm{CP}\right)$. TWS, TBS, TCS and TOH presented no significant differences in their $\mathrm{SN}$ content $(\mathrm{P}>0.05)$, averaging $431.8 \mathrm{~g} \mathrm{~kg}^{-1} \mathrm{CP}$.

The NDF, ADF, NDIN and ADIN contents of the yeast biomass were not affected by the type of substrate fermented. The average contents observed were $225.0 \mathrm{~g} \mathrm{~kg}^{-1} \mathrm{DM}, 58.5 \mathrm{~g} \mathrm{~kg}^{-1} \mathrm{DM}$, $89.3 \mathrm{~g} \mathrm{~kg}^{-1} \mathrm{CP}$, and $35.7 \mathrm{~g} \mathrm{~kg}^{-1} \mathrm{CP}$, respectively.

Effect of the type of substrate fermented on the productivity of the yeast protein concentrate

In all cases, the productivity was affected $(\mathrm{P} \leq 0.001)$ by the type of substrate fermented (Table 3). The highest value for YMPC/MSF was observed with the TSP (327.10 $\left.\mathrm{mg} \mathrm{g}^{-1}\right)$, followed by TOH (207.08 $\mathrm{mg} \mathrm{g}^{-1}$ ), TWS (193.02 $\left.\mathrm{mg} \mathrm{g}^{-1}\right)$, TBS (188.42 $\mathrm{mg} \mathrm{g}^{-1}$ ) and TCS (156.30 $\left.\mathrm{mg} \mathrm{g}^{-1}\right)$. Both for MCP/MSF and MTP/MSF, TSP presented the highest productivities (165.83 and $130.32 \mathrm{mg} \mathrm{g}^{-1}$, respectively). The lowest values were observed in TCS with MCP/MSF and
MTP/MSF values of 60.78 and $40.58 \mathrm{mg} \mathrm{g}^{-1}$, respectively. TOH was the next best substrate for both parameters (MCP/MSF and MTP/MSF), with a value of $98.35 \mathrm{mg} \mathrm{g}^{-1}$ observed for the former and $74.37 \mathrm{mg} \mathrm{g}^{-1}$ for the latter. TWS and TBS showed no differences in their production efficiency for either MCP/MSF or MTP/MSF with averages of 83.33 and $63.25 \mathrm{mg} \mathrm{g}^{-1}$, respectively.

\section{Discussion}

The effect of the type of substrate fermented by Sc on the nitrogen content fraction (CP, TP and $\mathrm{SN}$ ) in the yeast biomass generated can be explained by the magnitude and variation in the availability of energy and carbonate skeletons offered by the various substrates fermented together with the probable variation in the $\mathrm{N}$-fixing efficiency of $\mathrm{Sc}$ for protein synthesis. The higher proportion of $\mathrm{CP}$ and TP shown by the control (TSP) indicates that the cell growth level of Sc is favored by a rapid fermentation substrate, such as starch. During slow fermentation, Sc yeast mainly use the energy for maintenance, and in fast fermentation, excess energy is used for growth and reproduction. This implies the synthesis of protein (enzymes) with a consequential increase in CP. The information above suggests that the limiting factor for microbial protein content is energy availability rather than the availability of nitrogen sources. This is based on the fact that all the substrates evaluated had some content of CP in their chemical composition (Table 3), unlike SP for which the content is zero,

Table 3. Effect of the type substrate fermented on the productivity of the protein concentrate originated by Saccharomyces cerevisiae.

\begin{tabular}{|c|c|c|c|c|c|c|c|}
\hline \multirow[b]{2}{*}{ Productivity } & \multicolumn{7}{|c|}{ Microbial protein concentrate $\left(\mathrm{mg} \mathrm{g}^{-1}\right)$} \\
\hline & $\mathrm{TWS}^{1}$ & TBS & TCS & $\mathrm{TOH}$ & TSP & SEM & $\mathrm{P}$ \\
\hline $\mathrm{YMPC}_{\mathrm{MSF}^{2}}$ & $193.02 \mathrm{c}$ & $188.42 \mathrm{~d}$ & $156.30 \mathrm{e}$ & $207.08 \mathrm{~b}$ & $327.10 \mathrm{a}$ & 8.37 & $\leq 0.001$ \\
\hline $\mathrm{MCP} / \mathrm{MSF}$ & $83.60 \mathrm{c}$ & $83.06 \mathrm{c}$ & $60.78 \mathrm{~d}$ & $98.35 \mathrm{~b}$ & $165.83 \mathrm{a}$ & 1.23 & $\leq 0.001$ \\
\hline MTP/MSF & $63.49 \mathrm{c}$ & $63.01 \mathrm{c}$ & $40.58 \mathrm{~d}$ & $74.37 \mathrm{~b}$ & $130.32 \mathrm{a}$ & 2.28 & $\leq 0.001$ \\
\hline
\end{tabular}

Different letters within rows indicate differences $(\mathrm{P} \leq 0.05)$.

${ }^{1}$ TWS: treatment with the wheat straw substrate, TBS: treatment with the barley straw substrate, TCS: treatment with the chili stubble substrate, TOH: treatment with the oat hull substrate, TSP: treatment with the starch powder substrate.

${ }^{2} \mathrm{YMPC} / \mathrm{MSF}$ : yeast mass of protein concentrate/mass of substrate fermented, MCP/MSF: mass of crude protein/mass of substrate fermented, MTP/MSF: mass of true protein/mass of substrate fermented. 
and further by the addition of urea and peptone to the incubation medium. Thus the additional availability of these nitrogenous fractions in the incubation media would not imply a higher content of either CP or TP in the yeast biomass produced. It would seem that the addition of urea $(1 \mathrm{~mL}$ at $5 \% \mathrm{w} / \mathrm{v})$ and peptone $(1 \mathrm{~mL}$ at $2 \%)$ to the cultivation medium was sufficient to satisfy the $\mathrm{N}$ requirements for protein synthesis and also for nitrogenous metabolism of Sc.

In regards to the $\mathrm{TOH}$, one possible explanation for the higher $\mathrm{CP}$ content found compared to the other fibrous substrates fermented is that it may be due to the lower contents of FDN, FDA, NDIN and ADIN presented by this substrate (Table 1). The lower lignocellulose content would have favored the growth of cellular biomass in $\mathrm{Sc}$ when $\mathrm{OH}$ is fermented, most likely because the energy and carbonate sources become available more rapidly, resulting in the increased synthesis of microbial proteins and cellular growth. Nevertheless, the $\mathrm{SN}$ when $\mathrm{OH}$ was fermented was no different from that shown by the other vegetable substrates. Nor was there any difference in the TP content compared to TWS and TBS; however, there was a difference when compared to incubation with CS (TCS). It should be noted that the FDN and FDA contents of this latter substrate were the highest of all the substrates studied, which would most likely explain the lower rate of cellular protein synthesis during fermentation with Sc.

On the other hand, the NDF, ADF, NDIN and ADIN contents of the yeast biomass were not affected by the type of substrate fermented. Sufficient information is not available to explain this phenomenon; however, we suggest that the chemical composition and content of the yeast cell wall tends to vary little and would be, to some degree, independent of the magnitude of the population growth and/or the growth in cellular biomass productivity. Although the degree of dimorphism during the growth phases of Sc was not studied in this research, these observations suggest that this possible dimorphic change, which is a property of yeasts such as Sc (Casalone et al., 2005), presented no incidental variability in the contents of the fibrous fractions of the fungal biomass produced.

The $\mathrm{CP}$ content reached by $\mathrm{Sc}$ when the substrate $\mathrm{OH}$ was fermented (474.5 $\left.\mathrm{g} \mathrm{kg}^{-1} \mathrm{DM}\right)$, the highest of the fibrous substrates evaluated, is comparable to the $469 \mathrm{~g} \mathrm{~kg}^{-1} \mathrm{DM}$ of CP for the yeast Sc reported by NRC (2001). This content compares positively with the $410 \mathrm{~g} \mathrm{~kg}^{-1} \mathrm{DM}$ of CP for an extract of Sc yeast reported by Winkler et al. (2011).

Although in this study the highest $\mathrm{CP}$ content was obtained with the control (506.3 $\left.\mathrm{g} \mathrm{kg}^{-1} \mathrm{DM}\right)$, in general the results observed are promising because we were able to generate a protein concentrate with CP content close to $47.5 \%$ by fermenting a fibrous substrate.

With respect to the maximum YMPC/MSF, MCP/ MSF and MTP/MSF productivity shown by Sc when the substrate SP was fermented, it can be argued that the lower nutritional stress, which most likely occurred in the fermentation of starch, led to a greater availability of energy and carbonate skeletons for Sc metabolism, which translated into greater cell and population growth and thus resulted in the maximum biomass levels produced. Following the same assumptions might explain the greater productivity of $\mathrm{Sc}$ when $\mathrm{OH}$ was fermented than with the other fibrous substrates evaluated, due to the lower content of fibrous fractions present in $\mathrm{OH}$. In support of the statement above, from an ecological perspective, it has been suggested that nutrient availability would be one of the basic factors for determining the life cycle behavior of Sc. The induction of sporulation by fermentative stress (under slow-fermenting fibrous structures) might explain the lower cellular biomass productivity in the substrates with higher contents of lignocellulose fractions (Piccirillo and Honigberg, 2010).

The yeast mass productivity levels reached by Sc when incubated with SP and OH (327.10 and $207.08 \mathrm{mg} \mathrm{g}^{-1}$, respectively) are auspicious 
because, if a protein concentrate of yeast origin could be generated with an efficiency close to $20 \%$, it would be of interest given the volumes of these fibrous substrates, which are generated and discarded as waste in our region.

The results found in this investigation may suggest the use of lignocellulosic biomass (substrate) pretreatment over yeast fermentation, such as hydrothermal processing or fibrolytic enzymes treatments, to increase the production efficiency of Sc to ferment fibrous substrates (Peng and Chen, 2011; Ruiz et al., 2012).

In brief, a protein concentrate with a satisfactory $\mathrm{CP}$ and TP content can be obtained from the yeast Saccharomyces cerevisiae using fibrous substrates of agricultural origin by fermenting them in bioreactors. Another attribute observed for this cellular biomass was a low content of fibrous fractions (NDF and ADF). All of these findings suggest that this protein concentrate of yeast origin could be used for feeding non-ruminant animals. The productivity observed indicates the viability of this biotechnological alternative for the production of a low cost protein feed.

\section{Acknowledgments}

The authors are grateful for the collaboration of assistant Ing. Agr. MSc. María Isabel Martínez in the laboratory work. This project was funded by DGIP 2009308 of Universidad Católica de Temuco.

\section{Resumen}

A. Velásquez, R. Arias y M. Toneatti. 2012. Efecto del tipo de sustrato sobre la composición química y la productividad de un concentrado proteico originado por levadura. Cien. Inv. Agr. 39(3): 425-434. Se generaron extractos de la levadura Saccharomyces cerevisiae $(\mathrm{Sc})$ utilizando el método biotecnológico fermentación en estado sólido. El material orgánico usado para la fermentación consistió en una variedad de sustratos fibrosos de origen agrícola. Se evaluó el efecto de estos sustratos sobre la composición química y productividad de la biomasa celular. Los sustratos estudiados fueron: paja de trigo, WS; paja de cebada, BS; rastrojo de ají, CS; cáscara de avena, $\mathrm{OH}$ y almidón en polvo, SP (control). Para la incubación con Sc se agregaron $2 \mathrm{~g}$ de sustrato vegetal (seco) a $12 \mathrm{~mL}$ de medio de cultivo. El tiempo de fermentación fue de 7 días, bajo condiciones aeróbicas $\left(\mathrm{pH} \mathrm{5}\right.$, a $\left.26^{\circ} \mathrm{C}\right)$. Luego de la extracción de la biomasa celular se procedió a determinar su composición química y la productividad. Los resultados permitieron observar un efecto $(\mathrm{P} \leq 0,01)$ del tipo de sustrato vegetal fermentado sobre el contenido de proteína cruda (CP) y proteína verdadera (TP) en la biomasa de levadura. La mayor concentración de CP fue obtenido a través de la fermentación del control TSP (506,3 $\left.\mathrm{g} \mathrm{kg}^{-1} \mathrm{DM}\right)$, seguido por el tratamiento TOH $\left(474,5 \mathrm{~g} \mathrm{~kg}^{-1} \mathrm{DM}\right)$. La productividad de biomasa de $\mathrm{Sc}$ fue afectada por el tipo de sustrato fermentado $(\mathrm{P} \leq 0,001)$. El valor más alto fue obtenido con TSP $\left(327,10 \mathrm{mg} \mathrm{g}^{-1}\right)$, seguido por TOH $\left(207,08 \mathrm{mg} \mathrm{g}^{-1}\right)$. La menor eficiencia fue medida con TCS $\left(156,30 \mathrm{mg} \mathrm{g}^{-1}\right)$. Sobre la base de estos resultados se puede inferir que es posible obtener un extracto de levadura de Sc con un alto contenido de CP a través de la fermentación de sustratos fibrosos.

Palabras clave: Concentrado proteico, Saccharomyces cerevisiae, sustrato vegetal. 


\section{References}

Antier, P., A. Minjares, R. Roussos, and G.V. González. 1993. New approach for selecting pectinase producing mutants of Aspergillus niger well adapted to solid state fermentation. Biotechnol. Adv. 11:429-440.

Anupama, P., and A. Ravindra. 2000. Research review paper. Value-added food: Singlecell protein. Biotechnology Advances 18: 459-479.

AOAC. 1990. Official methods of analysis. Association of Official Analytical Chemists AOAC). $15^{\text {th }}$ Edition. Washington DC, USA.

Bai, F.W., W.A. Anderson, and M. Moo-Young. 2008. Ethanol fermentation technologies from sugar and starch feedstocks. Biotechnology Advances 26:89-105.

Brock. 1998. Biología de los microorganismos. Prentice Hall. 986 pp.

Bruno, R.G., H.M. Rutigliano, R.L. Cerri, P.H. Robinson, and J.E.P. Santos. 2009. Effect of feeding Saccharomyces Cerevisiae on performance of dairy cows during summer heat stress. Animal Feed Science and Technology 150:175-186.

Casalone, E., C. Barberio, L. Cappellini, and M. Polsinelli. 2005. Characterization of Saccharomyces cerevisiae natural populations for pseudohyphal growth and colony morphology. Research in Microbiology 156:191-200.

Domsch, K.H., W. Gams, and T. Anderson. 1980. Compendium of soil fungi. Academic Press. 859 pp.

El-Nawwi, S., and A. El-Kader. 1996. Production of single-cell protein and cellulase from sugarcane bagasse: Effect of culture factors. Biomass and Bioenergy 11:361-364.

Ferrer, J., G. Paez, E. Marmol, E. Ramones, H. Garcia, and C.F. Forster. 1996. Acid hydrolysis of shrimp-shell wastes and the production of single cell protein from the hydrolysate. Bioresource Technology 57:55-60.

Ghaly, A., M. Kamal, and L.R. Correia. 2005. Kinetic modelling of continuous submerged fermentation of cheese whey for single cell protein production. Bioresource Technology 96:1143-1152.

Golfinopoulos, A., N. Kopsahelis, K. Tsaousi, A.A.
Koutinas, and M. Soupioni. 2011. Research perspectives and role of lactose uptake rate revealed by its study using 14C-labelled lactose in whey fermentation. Bioresource Technology 102:4204-4209.

Jay, J.M. 2000. Modern food microbiology. 6th edition. An Aspen Publishers, Inc. Gaithersburg, Maryland. $679 \mathrm{pp}$.

$\mathrm{JMP}^{\circledR}$. 2003. Version 5.0.1.2, SAS Inc., Cary, NC.

Jung, E., H. Lee, U.J. Chang, S.H. Bae, K.H. Kwon, and H.J. Suh. 2010. Acute and subacute toxicity of yeast hydrolysate from Saccharomyces cerevisiae. Food and Chemical Toxicology 48:16771681.

Kacmar, J., A. Zamamiri, R. Carlson, N.R. Abu-Absi, and F. Srienc. 2004. Single-cell variability in growing Saccharomyces cerevisiae cell populations measured with automated flow cytometry. Journal of Biotechnology 109:239-254.

Kamel, B. 1979. Dates as a potential substrate for single cell protein production. Enzyme and Microbial Technology 1:180-182.

Lehloenya, K.V., C.R. Krehbiel, K.J. Mertz, T.G. Rehberger, and L.J. Spicer. 2008. Effects of propionibacteria and yeast culture fed to steers on nutrient intake and site and extent of digestion. J. Dairy Sci. 91:653-662.

Najafpour, G.D. 2007. Single-Cell Protein. Biochemical Engineering and Biotech. Amsterdam, Elsevier. p. 332-341.

Nielsen, J., and M.C. Jewett. 2008. Impact of systems biology on metabolic engineering of Saccharomyces cerevisiae. FEMS Yeast Res. 8:122-131.

NRC. 2001. Committee on Animal Nutrition, United States-Canadian, Tables of Feed Composition. National Research Council (NRC). Washington, DC, USA. 92 pp.

Nwabueze, T.U., and G.B. Oguntimein. 1987. Sweet orange (Citrus senensis) residue as a substrate for single cell protein production. Biological Waste 20:71-75.

Pakula, T.M., K. Salonen, J. Uusitalo, and M. Penttilä. 2005. The effect of specific growth rate on protein synthesis and secretion in the filamentous fungus Trichoderma reesei. Microbiology 151:135-143. 
Peng, L., and Y. Chen. 2011. Conversion of paper sludge to ethanol by separate hydrolysis and fermentation (SHF) using Saccharomyces cerevisiae. Biomass and Bioenergy 35:1600-1606.

Pereira, F.B., P.M.R. Guimarães, J.A. Teixeira, and L. Domingues. 2010. Optimization of low-cost medium for very high gravity ethanol fermentations by Saccharomyces cerevisiae using statistical experimental designs. Bioresource Technology 101:7856-7863.

Piccirillo, S., and S.M. Honigberg. 2010. Sporulation patterning and invasive growth in wild and domesticated yeast colonies. Institut Pasteur. Research in Microbiology 161:390-398.

Pichard, D.G., and P.J. Van Soest. 1977. Protein solubility of ruminant feeds. Proceedings of Cornell Nutrition Conf., Ithaca, N.Y. p. 91-98.

Robinson, T., and P. Nigam. 2003. Bioreactor design for protein enrichment of agricultural residues by solid state fermentation. Biochemical Engineering Journal 13:197-203.

Rollini, M., and M. Manzoni. 2006. Influence of different fermentation parameters on glutathione volumetric productivity by Saccharomyces cerevisiae. Process Biochemistry 41:501-1505.

Rostami, K., M. Moazed, D. Zareh, and A. Kheirolomoom. 2009. Single cell protein production using airlift reactor containing static mixer. Journal of Bioscience and Bioengineering 108:1389-1723. Ruiz, H.A., D.P. Silva, D.S. Ruzene, L.F. Lima, A.A. Vicente, and J.A. Teixeira. 2012. Bioethanol production from hydrothermal pretreated wheat straw by a flocculating Saccharomyces cerevisiae strain - Effect of process conditions. Fuel. 95: 528-536.

Sathesh-Prabu, C., and A.G. Murugesan. 2011. Potential utilization of sorghum field waste for fuel ethanol production employing Pachysolen tannophilus and Saccharomyces cerevisiae. Bioresource Technology 102:2788-2792.

Silva, C.F., S.L. Arcuri, C.R. Campos, D.M. Vilela, J. Alves, and R.F. Schwan. 2011. Using the residue of spirit production and bio-ethanol for protein production yeasts. Waste Management 31:108114.

Van Soest, P.J., J.B. Robertson, and B.A. Lewis. 1991. Methods for dietary fiber, neutral detergent fiber, and nonstarch polysaccharides in relation to animal nutrition. J. Dairy Sci. 74:3583-3597.

Villas-Bôas, S.G., E. Esposito, and D. Mitchell. 2002. Microbial conversion of lignocellulosic residues for production of animal feeds. Animal Feed Science and Technology 98:1-12.

Winkler, B., H. Tosi, A.J.F. Webster, F.D. Resende, A.A. Oliveira, and L.C.V. Villela. 2011. Dried yeast (Saccharomyces cerevisae) as a protein source for horses. Livestock Science 137:168177.

Zheng, Y., X. Chen, and Z. Wang. 2005. Microbial biomass production from rice straw hydrolysate in airlift bioreactors. Journal of Biotechnology 118:413-420. 